\title{
Palestine: \\ Popular Non-Violent Resistance. Debating Terminology and Constructing Paradigms.
}

\author{
Abdelrahman NAZZAL \\ Ayman YOUSEF
}

\begin{abstract}
The main goal of this research paper is to examine the core role of popular nonviolent resistance in transforming the Israeli Palestinian conflict through all available peaceful means. We have deeply gone through different definitions of nonviolence as an international concept and we explored the various historical stages and prominent stations of this type of nonviolence. To elaborate more on this goal, we can say that the strategic aim is to bridge the gap between theories and approaches of conflict transformations and the current study of peaceful resistance. Nonviolence is one strategic options for the Palestinians if we realize that the political alternatives and narrow and limited. Methodology adopted in this research is primarily qualitative with analytical and empirical connotations and implications, we relied on both primary and secondary data to reach the final results and conclusions. As far the final findings are concerned, this paper concluded that there is a gap between nonviolence peaceful resistance in the field in one hand and the decision makers on the other hand. There is a gap those who practiced or who embraced nonviolence as strategic resistance and those who put political goals and practiced political leadership. There is a lack of a proper understanding of peaceful nonviolent resistance and its role in

Abdelrahman NAZZAL liberating and emancipating Palestine from the occupation.
\end{abstract}

Arab-American University, Palestine

E-mail: abdelrahman.nazzal@aaup.edu

Ayman YOUSEF

Arab American University, Palestine

E-mail: ayman.yousef@aaup.edu

Conflict Studies Quarterly

Issue 36, July 2021, pp. 39-53

DOI: $10.24193 / \mathrm{csq} \cdot 35.3$

Published First Online: 05 July /2021
Keywords: nonviolence, occupation, popular resistance, Gandhian model.

\section{Introduction}

Historically, Palestinian popular resistance has never been a transitional optional extra, an accidental action that the Palestinians have recourse to in order to bring about an end to the occupation, liberate their 
homeland and reclaim their usurped rights. Rather, it has always been one of the fundamental individual and leadership approaches to struggling against the occupier, both at home and abroad. That struggle has gone through a wide range of stages during which popular resistance has garnered much collective attention in the quest for freedom and independence. From the early days of the occupation of Palestine onward, particularly during the first Intifada that erupted in 1987, popular resistance has been common, and it was only in the second Intifada that the Palestinians have clawed their way back from the relatively soft resistance to taking up the arms. Yet, that came only after ages of popular resistance, originated during the British Mandate and developed later during the Israeli occupation into different forms of protests, rallies, sit-ins, strikes and hunger strikes by Palestinian prisoners.

In the past few years, especially after Mahmoud Abbas took presidency office, popular resistance has started to gain ground thanks to a decline in armed operations, the lull maintained in the West Bank and the respite in the Gaza Strip. This period coincided with the tendency of the Palestinian leadership to adopt the popular resistance as a strategic tool in the face of the stalled peace process and Israel's refusal to conclude with the Palestinians an agreement that leads to all-out peace and allows the establishment of a Palestinian state on the land Israel seized in 1967. Having experienced the adverse effects of the second Intifada (a militarized revolt that harmed civil security and brought chaos and disorder in the final stages), it seems as though the Palestinian leadership has arrived at the conviction that the best way for the fight for freedom is popular resistance. That using the armed resistance on the ground to enhance the political position has proved to be unproductive has forced the Palestinian leadership to take more peaceful and diplomatic approaches to the conflict so as to unmask Israel, eventually forcing it to recognize the right of the Palestinian people to establishing their independent state.

The unfavorable context in the occupied Palestinian territory requires a shared resilience strategy based on a popular resistance approach that can be ingrained nationally. It is possible that all Palestinians, at home and abroad, adopt such an approach, each group within its sphere of influence: protests, boycott, artistic expression, diplomacy, media and solidarity. This would allow the Palestinians to end the internal divide and unite in the face of the occupation.

In this research paper, we examine the concept of popular resistance in the occupied Palestinian territories as perceived by the Palestinian leadership and field activists. We then outline the most important forms of popular resistance in the history of the Palestinian struggle, trying to find out whether popular resistance is a long-term strategy or a short-term tactic the Palestinian leadership has taken to resist the occupier. We later look at the most important obstacles to effective Palestinian popular resistance and the methods that can be adopted to overcome such obstacles. Finally, the chapter 
examines the applicability of international popular resistance models, as the Gandhi School of thought, to the Palestinian case.

\section{Theoretical paradigms}

In his article "Nonviolent Struggle and the harmony of the mean with the goal", Sa'ed Muddieh argues that all forms of popular resistance mainly focus on constructing and erecting a valuable international system for fighting against all forms of oppression and suppression and avoiding all violent bloody forms of resistance. Regarding the Palestinian issue, popular resistance is considered as a resistance against direct occupation and structural suppression that is used against the Palestinians (Muddieh, 2002, 181-191).

Gandhi Ideal School actually struggled nonviolently against the British colonizers in the Indian sub-continent. Gandhi mobilized goodness scruples and the humanity of the colonizers in addition to rational arguments with the enemy to end the occupation (Yousef, Foschi, \& Hidalgo, 2020). Mahatma Gandhi didn't only work on the theoretical aspects of nonviolence, but he also adopted and applied the philosophy of nonviolence in every aspect of peoples' daily life. He thought that people could only live in peace and harmony if they try to resolve all their conflicts peacefully and nonviolently since peace is a natural part and component of all humans. One remarkable change that Gandhi has achieved is that he was successful in convincing people at both, the individual and the state levels, that nonviolence is the sufficient weapon that is used by strong people, and it is never the weapon of the weak people. This has touched and affected the psychological aspects of humans who later on moved ahead towards using nonviolence as an effective way to settle the different kinds of conflicts they might be exposed to. Gandhi was called as the father of nonviolence, not because he was the first inventor of this theory, but because of his real and actual belief of this theory that he applied "He raised nonviolent action to a level never before achieved (Shepard, 2002, 1-10).

In his writings about the importance of nonviolence as a tool to struggle against the different forms of oppression, Mahatma Gandhi didn't forget to discuss violence with its two main forms and pillars: passive and physical violence. In his studies, he relies on "Himsa" ${ }^{1}$ that presents the psychological and physical harm that people might be exposed to. He also argues that to have a better understanding of nonviolence, we should first understand what violence is and what its root causes are.

Gene Sharp paradigm that mainly focused on realistic and pragmatic trends with zero attention to mobilizing goodness scruples of the colonizers. Gene Sharp has actually

1 "Himsa" is an Indian word that means injury. It is used in the Indian culture to stand for the different forms of violence and harm that is caused to others. 
been a bit more realistic in that he thought that people should struggle and fight against the colonizers, occupiers, and oppressors by using all the different nonviolent methods and tools. At the same time, he didn't believe in mobilizing the enemies' goodness because these oppressors don't actually have good morals that could be mobilized. He also called for the actual and real adoption of nonviolence inside all individuals who feel oppressed and want to get rid of that oppression (Sharp, 2005).

Gene Sharp deeply explores and analyzes the political implications and advantages of mobilizing the nonviolent action to apply people power in conflict resolution (Sharp, 2013). Gene Sharp thinks that states derive their power from its citizens' obedience, and if people disobey the rulers, the country will no longer has any political, social and economic power. Hence, all oppressed people have to work together as on hand to stand in the face of the occupation and the oppressors to get all their stolen rights back and to live a peaceful life. This could only be done by constructing a strong fan base and masses of nonviolence.

In other words, Sharp has always stated that people or "subjects" as he used to describe them are considered as the main and most important sources of the state's power. These people can achieve any pragmatic changes in any state if they are unsatisfied with the conditions in that country, and this could be mainly achieved through the disobedience of the ruler and the governing system (Sharp, 2005). Up to that point, it is very important to know that some people who have interests with the government, especially the elites and the businessmen, will not be a part of the nonviolent movement that struggle against a certain regime. This is mainly due to the fact that these people want to preserve their own business and interests with the oppressive government or regime.

In his book "Stride toward Freedom", Martin Luther King discussed the very high and precious values and effects of love and morals in resolving conflicts peacefully. He thought that nonviolence that was previously used by Gandhi was the most effective weapon that could be used by people to defend their rights. They could also struggle nonviolently to get rid of all the different forms of oppression and suppression that might be imposed by the colonizers, occupiers or suppressive regimes (King, 1958, 94-112).

King was also highly affected by the Gandhian model of nonviolent resistance, and he benefited a lot from his visit to India in 1959. He was highly inspired by Gandhi "To other countries I may go as a tourist, but to India I come as a pilgrim" and he learned a lot from the bus boycott that was initiated and performed by the Indians (Brockel, 2020). This trip also mastered his understanding of nonviolence and enriched and empowered his commitment for his struggle for the civil rights in America.

Up to King, it is very important to fight against the different forms of evil in order to have tangible results of the nonviolent resistance. He also adds that it is very important to build and plant the good morals in all people to have a successful nonviolent resist- 
ance. Without love and friendship, nonviolence would achieve nothing, and people will not achieve their goals in freedom, liberty and peace. People should first learn how to forgive and forget the pains and injuries of the past before they start their struggle against oppression and injustice. Moreover, King calls for the internal cleaning of individuals, who should be internally pure and clean to manage their resistance against suppression (King, 1958: 88-89). In short, we can say that Martin Luther King pays a very important attention and gives a very high value for the implementations and psychological meanings of nonviolence, and he supposes that nonviolence would achieve nothing without love, friendship, morals, forgetting and forgiveness.

\section{Mazin Qumsieyh: Popular Resistance in Palestine:} A history of Hope and Empowerment

"This is a timely and remarkable book written by the most important chronicler of contemporary popular resistance in Palestine. Mazin Qumsiyeh brilliantly evokes the spirit of Mahatma Gandhi, Edward Said, Rachel Currie and many others, to tell the unvarnished truth about Palestine and Zionist settler colonialism. With its focus on 'history and activism from below', this is a work of enormous significance. Developing further his original ideas on human rights in Palestine, media activism, public policies and popular, non-violent resistance, Mazin Qumsiyeh's book is a must read for anyone interested in justice and how to produce the necessary breakthrough in the Israel-Palestine conflict." (Masalha, 2007, 25)

Qumseiyeh's book "Popular Resistance in Palestine: A history of Hope and Empowerment" first derives its importance because it is written by a Palestinian scholar and professor who has survived the occupation from a long time. This book is divided into fourteen chapters that deeply go through the history of the Palestinian popular nonviolent resistance beginning from the Ottoman rule, progressing during the 1936 revolution, the first and second Intifadas and the nonviolent resistance today. Qumsiyeh provides a very clear historical analysis of the nonviolent actions that the Palestinians followed in the past, and how they learned from these experiences to empower the Palestinian nonviolent resistance today (Qumsieyh, 2011,1-12). It also gives a description of nonviolent resistance in Palestine nowadays, and how Palestinians try to adopt this form of resistance in spite of the absence of a real leader who can lead them in their nonviolent struggle against the occupation.

His work is also positively distinguished by its recommendations for more pragmatic and fruitful results of the popular nonviolent resistance in Palestine. He thinks that this form of resistance is of very high importance because it refutes the allegations and claims that Palestinians don't believe in the efficiency of nonviolent resistance. Today, many of the countries around the world describe the Palestinian struggle against the Israeli 
occupation as a violent struggle in spite of that Palestinians have no developed weapons. They also try to solve this prolonged conflict through the negotiation process that has achieved nothing until now. Hence, Qumsieh tries to convince the international community that Palestinians are peace seekers and they try to solve the Israeli-Palestinian conflict peacefully. He finally calls for adopting this form of resistance to free Palestine, and Palestinians should have a real fan base that leads this form of resistance. Without having good leaders of nonviolence, Palestinians would never achieve their goals of liberty and freedom (Qumsiyeh, 2011, 11-12).

In order to achieve tangible results, nonviolent resistance movements should work hard on increasing the cost of the repressive policies of the regimes that would finally lead to reduction of using brute forces and lethal weapons against the public movements. This would help in the loss of legitimacy of the colonizers, and they will have fewer supports from the local and foreigner allies.(Galtung, 1989, 30-40).

\section{Popular resistance: Terminology debated}

Beyond the literal meaning of the term, 'popular resistance' for Palestinians it is a reference to any method the people can use in their struggle against the Israeli occupation: its soldiers, settlements and military and economic facilities. Perhaps the best resistance strategy is harnessing all resources in a way that is not intended to kill or harm others (the non-use of firearms attests to this and constitutes the boundary between popular resistance and armed resistance), which also allows all segments to take part, each in their own way. The Palestinian Authority has contributed to the development of the popular resistance paradigm (Personal Communication, 12-1-2019). Particularly after the political split with the Hamas-ruled Gaza Strip in 2007, it has focused on institutionalization, sustainable development, transparency and raising the banner of nonviolent resistance as a lever for negotiation. In the last five years, the Palestinian strategy, in order to deal with the occupation, has changed considerably and become definable by three major variables: nonviolent popular resistance; institutionalization and sustainable development; involvement of international public opinion and solidarity. As we hope to demonstrate, several factors have prevented this strategy from becoming effective. Resistance is rejection and non-acceptance, and in a revolutionary sense, it suggests rising up against persecution and adverse reality. Resistance wins legitimacy when it is initiated by the people, and real mobilization occurs when the majority takes to the streets and revolts against oppression (revolution in Syria, protests against waste crisis in Lebanon, bread prices riots in Jordan, electricity crisis in Gaza, and late crisis of public servants salaries in the West Bank) (Yousef, Foschi, \& Hidalgo, 2020).

According to Mustafa Shita, Secretary General of Al-Horiya Theater in Jenin, resistance can be described as nonviolent, but not peaceful. He argues that resistance and peace are mutually exclusive concepts; the one suggests the absence of the other. "Characterizing 
resistance as 'peaceful' is only a political newspeak. There is no such thing as peaceful resistance, and popular resistance suggests all forms of struggle and is always responsible for the results (Personal Communication, 5-1-2019).

Quite close to how freedom fighters define 'popular resistance' is the way the Palestinian leadership understands the term, though the latter is more inclined to nonviolent strategies to end the occupation. Nonviolence in this sense entails "all peaceful approaches that take into account the international opinion, as for liberation to be fulfilled there should be a set of key foundations, among which are mobilizing the international community and making the colonial occupation pay the price, this time through exerting direct leverage over the Israelis themselves as well as pressures from the international community (Personal Communication, 5-1-2019).

For Palestinian leftists, popular resistance is an umbrella term that must not be confined to nonviolent approaches, which, they believe, strip popular resistance off its impetus and deny the Palestinians the internationally-accepted methods of resistance. "Resistance should be nation-wide; and all forms, both violent and peaceful, should be legitimate. As many others in the Palestinian history of resistance, Kanafani and Barghouti-albeit his role as military commander during the Second Intifada and his present role, even if imprisoned, as a political leader-can be described by what Gramsci defined as organic intellectuals when the national struggle is taken into consideration (Yousef et al., 2020). Unfortunately, the leadership's understanding is very narrow; and as such it prevents the people from exercising their right to resistance. In the leadership account, popular resistance suggests peaceful methods, though what we are facing is a colonial, racist, settlement-based occupation that knows only the rule of the gun. As such, and under international law, all forms of resistance should be taken, including popular resistance (Personal Communication, 5-2-2019).

Popular resistance is one of the most important modes of engagement adopted by the Palestinians in the face of the occupation. The Palestinians have relied on mass mobilization to win international sympathy, make the Palestinian Cause central to international politics, and record gains on the ground, most importantly forestalling the occupier's policies of blockade, restrictions, land confiscation and settlement expansion. This goes in line with what have already argued that his important issue affected the holistic Palestinian public life in different areas: economic, social, political, etc. It is noted that the strong presence of different Palestinian civil society organizations highlights the great importance of their role in peacebuilding actions internally and externally at the local and elite levels (Yousef \& Ozcelik, 2021).

Mohammed Shtayeh, Palestinian Minister of Public Works and Housing, pointed out that in the Palestinian official discourse, a reference to resistance as a concept is virtually a reference to resistance as a practice, for it is imperative to embrace subtle popular resistance modes, for example placing posters on all road signs giving directions to colonial 
settlements, or taking part in peaceful rallies. This form of resistance can comfortably be called 'smart resistance'. "We should recall the first Palestinian Intifada, which then gained popular momentum and grabbed the attention of international community, thus making the Palestinian resistance visible to the world" (Personal Communication, 10-2-2019). Smart resistance, therefore, should consider all styles of nonviolent action, thus shaming revealing to the world the true face of the occupier, and making the occupation enterprise all the more costly to the Israelis.

This form of resistance would become an episode in the resistance landscape that started back in the 1930s. According to Ghassan Daghlas, a PA official in charge of monitoring settlements, certainly, the new form would vary in magnitude and oscillate depending on the overall context. "Such oscillation will be guided by central events related to the political scene, religious issues or a political enterprise that Israel wants to pass. This will be culminated in a mass mobilization" (Personal Communication, 5-2-2019). Bottom line conclusion, the policies adopted by Israel and carried out by its soldiers play a major role in shaping the popular resistance, lending it different forms depending on real developments; i.e., the nature and forms of the popular resistance are largely influenced by the policies and arbitrary measures taken by the occupier.

Some may argue that listing 'smart resistance' under peaceful popular resistance is unwise, assuming that all popular resistance modes, including armed forms, are guaranteed under international humanitarian law. This is true; however, it is the context that decides the way we take in the fight for our freedom. Fatah, for example, has not renounced the armed struggle from its program. Its decision-making community believes that each political stage requires specific tactics (for example, the transition from armed struggle to urban military operations). Salwa Hdeib, Member of Fatah Revolutionary Council, made the point that Fateh started and led the first Intifada before sitting at the negotiations table following the Oslo Agreement. Fateh espoused field peaceful action side by side with military action, believing that the military work is a valid option, a lever for effective diplomacy (Personal Communication, 5-1-2019).

Field activists add new dimensions to the term. For them, popular resistance is any anti-occupation action: boycotting goods, peaceful protests, sit-ins and even mass civil disobedience (Personal Communication, 18-1-2019). Local activists, especially those with direct contact with the occupation and its soldiers stationed at friction points and those who regularly stage protests near land slated for or threatened with confiscation, have a definition very much like the one adopted by the official Palestinian leadership: the use of all forms of popular struggle, including steadfastness; protecting the land through reclamation and cultivation; promoting volunteering and cooperation; and filing cases against the occupier locally and internationally. For Abdullah Abu Rahmeh, a popular resistance activist, the best method for the popular resistance is the civil mass demonstrations that inflict heavy losses on the occupier, expose its violent barbaric 
policies and draw international solidarity and participation in anti-occupation rallies. "These actions should work in parallel with efforts to support the "boycott, divestment and sanctions' movement, all serving the political endeavors of bringing Zionists to international courts and urging international organizations to support the rights of the Palestinians to freedom, independence and statehood" (Personal Communication, 4-2-2019).

Popular resistance in our view is a wide concept, which implies first and foremost getting a vast number of civilians engaged in a popular movement aimed at reaching certain objectives without using arms or causing physical harm to anyone. In Palestine, Fatah relies on encouraging people to express their views against the violent Israeli occupation by demonstrations. People must be able to speak out for their freedom seeking independence. It is crucially important in this regard not to use violent means in order not to give the occupiers a pretext for using more violence against our civilians. This is not to deny that Fatah has been engaged in continuous warfare with Israel for decades. But for now we believe war is not what we need (Personal Communication, 27-12-2018).

\section{Replicating the Gandhian Model in Palestine}

Copying the Gandhian model in Palestine is simple yet hard. As the leadership has yet to fully engage in the popular resistance, a Palestinian Gandhi is unlikely to exist. Of course, there are individual initiatives from people in power to take part in popular resistance. However, to create a model, we need a godfather, a folk hero who plays a leading and innovatory role in patronizing all national bodies representing popular committeesone that can design a well-defined strategy which inspires all Palestinians to follow.

Ho Chi Minh, a Vietnamese communist revolutionary leader, once said, "Each nation has its own shoe, and it knows how to use that shoe to walk on its soil." If anything, each nation has its particular and objective factual circumstances. It is thus possible to consider successful examples set by other nations and revolutions, but it is not necessary to reproduce their experiences. Instead, every Palestinian can be a Gandhi, because the talk is not about figures and individuals. In the fight for freedom, all fathers and brothers of martyrs as well as all prisoners can set examples of Gandhi (Personal Communication, 15-1-2019). It is not, thus, about reproducing international models; rather, it is a strategy based on a productive popular resistance ideology that capitalizes and builds on the expertise of other nations in resisting and ending the occupation.

According to Father Abdullah Brunella, Fateh member and Christian cleric, the Indian model cannot be reproduced as the situation is different: British-colonized India is totally different from Israeli-occupied Palestine; the Indians are different from Palestinians; Palestinians easily bow out of the show; and the popular resistance in the Palestinian context might turn into a festival (Personal Communication, 16-1-2019). 
Two key closely-related elements are fundamental to building on international models of popular resistance, particularly the Gandhi model. First, strenuous efforts are needed to help people work off frustration and give them hope of possible change. Second, we need a leader (leaders), a charismatic one with internal drive that can inspire people and magnetize all those believing in effective popular resistance. Hisham Sharabati, Coordinator of the Hebron Defense Committee, noted that this is no easy job to do as the current situation is quite disappointing. "Perhaps we have one or more examples of Gandhi in Palestine; however, the frustration state has yet to make people gather around "the present Gandhi", and perhaps we are still awaiting a new Gandhi with more powers, principles and innovation. Before the Gandhi example thrives and takes roots, it is expected to collide with PA-Israel security coordination because one of the most important foundations of nonviolent struggle is divorcing from the enemy, breaking with all obligations towards it, which blows up the PA's commitments" (Personal Communication, 18-1-2019).

Some Fatah leaders believe that Gandhi as a mythological hero rather than a miracle. What he did can be done by others if they are willing and if there are real principles based on well-defined goals of freedom and liberation. "Creating a Palestinian Gandhi requires reproduction of the methods not the individual. After all, there are many Palestinian leaders who can be Gandhi-like and achieve the same goals that Gandhi managed to achieve if they receive adequate public support. (Personal Communication, 5-2-2019).

In practice, however, there exist some obstacles that may impede employing Gandhi's authentic model. It is not difficult to forge Palestinian leaders who believe in nonviolent resistance, but such leaders will have to deal with two challenges. First, they need to prove to the public that peaceful resistance can achieve the envisioned goals. Second, their principles are likely to collide, so to speak, with the long-held views of other Palestinian factions or individuals who believe that armed resistance is the only way Palestinians can take in their struggle for freedom. From their viewpoint, the British Mandate in India, basically controlling the means of production, is way different from the Zionist colonial expansionist enterprise, which aims to uproot the Palestinians to make room for colonial settlers (Personal Communication, 5-2-2019).

\section{Palestinian popular resistance in the official discourse}

We first have to make the point that though popular resistance is imbedded in national struggle, it is not an alternative for other methods of resistance. Even when popular resistance is taken as a tactic at a given point, it should ultimately work to further the national unwavering strategy of fighting the occupation, which should culminate in liberation and independence.

At the internal level, popular assistance is highly acclaimed among the Palestinian leadership and all factions, which have incorporated the method in their political programs 
(e.g. Fateh has embraced this method in its last conference). However, it is unclear whether these factions have actually translated words into actions, with popular resistance still confined to some villages and few people. Major cities and some camps- which make up the majority of the population-are not engaged, not at all.

People in the Palestinian presidency do believe in popular resistance as a Palestinian strategy to confront and end the occupation. According to Hosam Zamlat, Palestinian President Advisor for Strategic Affairs, the Palestinian leadership believes in the effective role that the popular resistance can play in confronting the Israeli occupation, keeping a tight grip on it and unveiling its crimes against the armless Palestinians. He, however, held that popular resistance is seasonal, occurring in irregular, sporadic instances and usually driven by certain events, which once they are over, the momentum slacks off. Zamlat believes that a successful popular resistance needs a collective understanding and an unwavering volition (Personal Communication, 6-2-2019).

Some Palestinians in the Diaspora, typically taking a hard line on Palestinian national aspirations, say that popular resistance was part of the strategies of the Palestinian leadership until the 1987 Intifada (the Stones Intifada), after which the Palestinian leadership, the decision-making body in the Palestine Liberation Organization, has as though used that Intifada in a futile tactic, the price of which is still being paid by the Palestinians. These Palestinians wonder how the leadership can surrender its holding power in the ongoing conflict and having no teeth in the negotiations with a heavilyarmed opponent. According to Marwan Abdel A'al, Member of the Political Bureau of the Palestinian Popular Front, ever since the Palestinian leadership has adopted the political path as a strategic method to achieve its goals, it has switched to 'nonviolent smart resistance,' thus demeaning the small-scale popular resistance into an ineffective tactic, security disorder or otherwise skirmishes intended for mere pressure (Personal Communication, 27-1-2019).

For the Palestinian youth on the front, the Palestinian leadership had to acquiesce to the public bearings. "Having grown weary of the stalled negotiations, the Palestinian leadership has unanimously adopted popular resistance and supported its activities so as to make the Palestinian Cause take a center stage in international politics in light of Israel's refusal to freeze settlement construction. In the narrow sense, popular resistance for the Palestinian leadership is a disruption to the policies and plans of the Israeli occupation" (Personal Communication, 5-2-2019).

Technically speaking, the vast majority of people in the Palestinian leadership and factions approve of popular resistance. Khaled Mansour, Member of the Political Bureau of the Palestinian People's Party, says in practice, however, there is rapture between different groups. "Some want it to be a mere controllable tactic; others construe it as a strategic approach that needs to grow larger into a pattern that can always inflict losses on the occupation" (Personal Communication, 26-2-2019). To thrive, this form of 
resistance requires unification of all factions and political parties that would collectively adopt a clear-cut strategy with potentials to make Israel pay for its colonial occupation.

For common sense to prevail, we should always take 'adoption' as synonymous to 'action.' "All groups, even Hamas, believe in popular resistance as an effective approach under the existing circumstances. In practice, however, different groups are not equally engaged in popular mobilization. The promotion of the popular resistance approach requires a solid-rock faith whose remnants still exist among some people in different factions and independent parties. Such people can set a model and promote popular resistance, and even draw the official leadership to take part" (Personal Communication, 25-2-2019).

Popular resistance has garnered attention from the Palestinian official leadership. Baha' Froukh, Popular Resistance activist, noted that the majority of political parties and factions have incorporated this approach in their political programs. "Even Hamas and Islamic Jihad have, in reconciliation meetings and press statements, proclaimed support of popular resistance. On the ground, nevertheless, leaders are invisible and real engagement is restricted to a limited number of activists" (Personal Communication, 5-2-2019).

Obviously, there is a gap between beliefs and actions. The absence of support mechanisms for different actors has weakened popular resistance, rendering it ineffective, at least for the time being.

\section{Popular resistance versus non-violence}

International organizations and some Palestinian groups are trying to identify popular resistance with nonviolence. As Omar Mansour, Member of the National Initiative, put it, this is only misreading of the situation and for somewhat prosaic reasons. "There is little to suggest that popular resistance can be blunted and equated with nonviolence. This is counterintuitive, as in the real world, popular resistance is not limited to soft approaches; some force can do no harms, which is not the case for nonviolent methods. Proponents of nonviolence have so far failed to demonstrate how soft resistance can translate into actual confrontation with the occupier" (Personal Communication, 22-2-2019).

A class of the political elite believes that popular resistance can be both nonviolent and violent, with the former being restricted to particular circumstances. "The ability to manage resistance is part of conflict management, which involves, among other things, harnessing all resources to act in different possible ways under all contexts (time, space, collective and individual conditions) based on regional changes, international balance of powers and local developments, especially the political divide. This myriad of determinants requires an efficient leadership, one that can behave in an 
intelligent and complex manner for the furtherance of the envisioned goals" (Personal Communication, 19-2-2019).

Resistance can take several forms, and when it enjoys mass participation, it becomes popular. According to Esam Nassar, researcher and professor at the University of IllinoisChicago, violence is always restricted to a small number of people within groups. "More often than not, nonviolent popular resistance tries as much as possible to avoid using firearms. But mass chaos sometimes unleashes violence against different things, so nonviolence in popular resistance suggests the absence of weapons. However, in the case of Palestine, physical or verbal violence against far-reaching, subjugation-seeking physical impediments (such as the separation wall, the occupation and soldiers) is part of the popular resistance. The occupation is inherently the worst form of organized violence against peaceful people" (Personal Communication, 12-1-2019).

There is disagreement among people we interviewed as to whether violence is part of popular resistance. Wafa Zakarneh, member of the Fatah Revolutionary Council, argues that violence is imbedded in popular resistance against the occupier which spares no means to inflict violence, injustice and oppression upon the armless Palestinians, an occupier that is determined to control another nation's existence and political destiny. "Popular resistance involves two main forms: peaceful popular resistance and armed popular resistance" (personal communication, 1-2-2019).

For some people, nonviolent resistance is synonymous with popular movement. Salah Abdel Ati, Director of Masarat Center for Studies in Gaza, reasons that they are the same because the purpose of popular resistance is to inflict economic and political losses on the Israeli occupation in order to weaken it. He believes that a Palestinian popular movement should mark different forms of protests, demonstrations, insurrection, rallies and boycotts, with as little violence as possible (personal communication, 18-1-2019).

Naturally, popular resistance should be holistic, incorporating both violent and nonviolent methods. Violence can be moral as long it seeks to stop further harm or achieve certain political gains. Nonviolent resistance in the Palestinian context is part of the popular action, as at the end of the day it seeks to realize national goals. he IsraeliPalestinian peacebuilding requires multiple perspectives and solutions with complex thinking as well as cognitive, behavioral, and affective changes in multiple levels from interpersonal to global (Yousef \& Ozcelik, 2021).

\section{Popular resistance as a part of the Palestinian strategy}

Palestinian popular resistance, in theory and as understood by the official level, is a realistic strategy responding to the imbalance of powers in the conflict. Indeed, all Palestinian factions have incorporated this form of struggle in their programs and promoted it in their conferences. Salah Abdel Ati, Director of Masarat Center for Studies in 
Gaza, says in practice, however, these factions have failed to build popular resistance enablers within their organizations; the so-called Third Intifada (the habba) is a real world example of the gap existing between words and actions. "Today, the Palestinian factions are divided into three groups. The first raises the banner of popular resistance while it is bound by international conventions that restrain ground actions. Worse, this group has in many cases clamped down on popular movement. So does the second group, which again courts popular resistance only to embarrass the first group and to compete for media presence, as part of recrimination episodes between the two groups. Hamas, I should say, belongs to the second group. The third class also raises the banner of resistance; yet it has not prepared its members for action, nor has it set the foundations for real confrontation. This group, with connections to PLO and its privileges, is fond of high-flying rhetoric only to appease its followers" (Personal communication, 15-2-2019).

Haj Sami Sadeq argues that a distinction between popular resistance and non-popular resistance does not seem to do justice to the term. He refuses this distinction, maintaining that resistance has never been a core part of the Palestinian leadership agenda. "For Ramallah decision-making community, resistance is only a short-term tactic. However, it should be made clear that resistance is more of a means to an end rather than an end in itself. After all, resistance aims to create a new life. Even with the strictest sense, the ascetic dimension of the issue does not exist. We do not live for resistance; we live for life; and resistance is a call for life not death. I think that Palestinians lack a welldefined strategy, and I do believe that nowadays the Popular Front and Islamic Jihad are the only two factions that are still raising the banner of resistance despite their limited resources. The two factions- though with different ideologies- have maintained a system in place to advocate resistance as the only way to liberate Palestine" (Personal Communication, 5-2-2019).

Na'em Morrar, Coordinator of Popular Resistance Follow-up Committee, notes that popular resistance has remained an empty slogan. The official level has not adequately supported resistance. Of late, resistance has started to pick up speed, thanks to initial support from the official level, particularly since the start of the popular Habba. Few months after the Habba started, however, signals from reality pointed to a desire by people in power to relax it. "The Palestinian leadership should have chosen to support popular resistance by building bridges of cooperation with national factions and popular committees, as well" (Personal Communication, 9-1-2019).

From a Fatah point of view, one should not limit their means to just one! You have to create many options in the various decades. We have had many full-fledged wars with Israel since 1968. That was repeated on a continuous base in the form of military operations called amaliyyatfidaeyya "jihadist operations" as we saw between 1960 to 2005. We had wars between Fatah and Israel in 1978, 1981 and 1982. Then we had 
the longest war between 2000 and 2005. But we have also the non-violent form of resistance added to our diplomatic struggle. With the increased crisis for negotiations and the strenuous search for exit solution for the Israeli dilemmatic situation due to demands for Israel to freeze its settlement activities and thus submit to the Palestinian precondition for the resumption of the negotiation process (Yousef \& Mohanad, 2013).

We saw this in the UN Security Council which passed the resolution 2334 calling for an end to Israeli settlement building. Today, we have 70 states and 5 world organizations meeting in Paris to discuss how to help the two state solutions stay alive. If you look at Hamas, they did not start armed struggle against Israel until they created the Qassam Brigades in 1991.

In this year they carried out their first operation against the Israeli military killing one Israeli soldier. That is 30 years after Fatah used arms against Israel. But now Hamas is not shooting and Israel is in an easy situation with regard to Gaza but it is in a tensed relation to President Abbas and Fatah because of the overwhelming international consensus in supporting our ideas, which Hamas does not share. (Personal communication, 10-2-2019)

\section{References}

1. Brockel, G. (2020). 'To India I come as a pilgrim': Martin Luther King Jr's remarkable trip to honor his hero. Washington Post. Retrieved from https://www.washingtonpost. com/history/2020/01/20/martin-luther-king-india-gandhi/.

2. Galtung, J. (1989). Nonviolence and Israel/Palestine. Institute of Peace at University of Hawaii.

3. King, M. L. (1958). Stride Toward Freedom. Harper and Row Publisher.

4. Masalha, N. (2007). The Bible and Zionism. Zed Books.

5. Muddieh, S. (2002). The nonviolent struggle: Harmony between the means and the goals. Roaya Journal, 2(16), 181-191.

6. Qumsieyh, M. (2011). Popular Resistance in Palestine: A history of Hope and Empowerment. Pluto Press.

7. Sharp, G. (2005). Waging Nonviolent Struggle "20 th Century Practice and $21^{\text {st }}$ Century Potential". Library of Congress Control.

8. Sharp, G. (2013). How nonviolence works. The Elbert Einstein Institution.

9. Shepard, M. (2002). Mahatma Gandhi and his Myths, civil disobedience, nonviolence and Satyagraha in the real world. Shepard Publications.

10. Yousef, A., Foschi, L. Checa H., D. (2020). The Palestinian Resistance: Nonviolent Praxis in a Gramscian Paradigm. Campos en Ciencias Sociales, 8(2), 73-110.

11. Yousef, A.,\& Ozcelik, S. (2021). Palestine: Reconciliation and Peacebuilding. Perspectives from the Civil Society Organizations. Conflict Studies Quarterly, 35, 98-109.

12. Yousef, A., \& Mohanad, M. (2013). Netanyahu's Strategy: A Question of Occupation and a Dilemma of Recognition. International Journal of West Asian Studies, 5(1), 61-76. 